\title{
Alternative Food Economies and Transformative Politics in Times of Crisis: Insights from the Basque Country and Greece
}

\author{
Rita Calvário \\ Institute of Environmental Sciences and Technologies (ICTA), Universitat Autònoma de \\ Barcelona, Barcelona, Spain; \\ ritamcalvario@gmail.com
}

\section{Giorgos Kallis}

Institute of Environmental Sciences and Technologies (ICTA), Universitat Autònoma de Barcelona, Barcelona, Spain and Catalan Institution for Research and Advanced Studies (ICREA) and Department of Development Studies, SOAS, University of London, London, UK

\begin{abstract}
Why and how do alternative economies emerge, how do they develop and what is their contribution, if any, to transformative politics? Alternative economies proliferate in the countries worse hit by economic crisis and austerity, such as Spain or Greece. Yet the existing literature is stuck in a counter-productive division between celebration and critique. We move beyond this division applying philosopher Daniel Bensaïd's understanding of politics to two alternative food economies, one in the Basque Country and one in Greece. We illuminate the activist strategies and specific conjunctures within which the two alternatives emerged and explain how they develop in the face of political-economic barriers. Alternative economies, we conclude, can be transformational when they are inserted in activist strategies directed to extend conflict, social struggles and challenge the capital-state nexus.

Resumen: ¿Por qué y cómo emergen las economías alternativas, cómo se desarrollan y de que manera contribuyen, si es que lo hacen, a la política transformadora? En los países más afectados por la crisis económica y las políticas de austeridad, como España o Grecia, proliferan experiencias de economías alternativas. Sin embargo, la literatura no ha discutido más allá de las visiones o bien celebradoras o bien críticas de las economías alternativas, generando una división contra-productiva para la análisis. En este artículo vamos más allá de esta división, aplicando la comprensión de política de Bensaïd a dos economías alimentarias alternativas, una en el País Vasco y una en Grecia. Mostramos las estrategias de activismo y coyunturas específicas dentro de la cuales surgieron ambas alternativas y explicamos cómo se desarrollan frente a barreras institucionales y económicas. De esta manera, concluimos que las economías alternativas pueden ser transformadoras cuando se insertan en estrategias activistas dirigidas a ampliar los conflictos y las luchas sociales desafiando el nexo entre capital y estado.
\end{abstract}

Keywords: alternative economies, transformative politics, crisis, food alternatives Palabras-clave: economías alternativas, política transformadora, crisis, alternativas alimentarias 


\section{Introduction}

Every day more and more Spaniards leave the asphalt for the countryside: ... youngsters and families return to the countryside searching for a life that is more sustainable, quiet and affordable ( $A B C$ 2013).

[The "no middlemen" movement] is typical of the new and inventive ways Greeks are finding to help themselves and each other in the country's fifth straight year of recession (The Guardian 2012).

There is a documented rise of alternative economies in contexts of economic crisis and austerity policies that reduce wages and shrink the welfare state (see Rakopoulos 2014, for Greece; Conill et al. 2012, for Spain; Abramovich and Vázquez 2007, for Argentina). Alternative economies refer to forms of "production, exchange, labour/compensation, finance and consumption that are in some way different from mainstream capitalist economic activity and give occasion to rethinking the economic system in itself" (Hillebrand and Zademach 2014:9). Some see in the recent rise of alternative economies a potential for radical social change, with the formation of a new economic culture (Castells et al. 2012) or social fabric (De Angelis 2012).

For anti-power (Holloway 2010), counter-power (Hardt and Negri 2009) and anarchist (Graeber 2002) theorists, social change will not come by seizing or influencing state power. It will come by expanding new social forms, spaces and practices "outside" capitalism, emptying the state gradually from its relevance. Theories of anti-power call for dissolving power by expanding de-commodified spaces (Holloway 2010), whilst theories of counter-power emphasize the power of the "multitude" to flee from subordination and exercise power in non-capitalist spaces, resisting continuously capitalism's attempts for co-optation (Hardt and Negri 2009).

A related literature on diverse economies focus on documenting non-capitalist forms of production. In adopting a non-capitalocentric view of the economy, the objective is to render alternatives visible and stimulate a "politics of possibilities" towards a post-capitalism future (Gibson-Graham 1996, 2006). For anarchist, autonomist and diverse economies theories alike the challenge is how to expand and connect different "cracks" within the capitalist system, with a logic of affinity and not of hegemony.

Starting perhaps with the confrontation between Marx, Engels and "utopian" socialists and anarchists, there is a long lineage of Marxist thought critical of alternative economies. Harvey, for example, recurrently argues that alternative economies have no autonomy from competition and the coercive state and that, often unintentionally, facilitate a neoliberal agenda of dismantling the welfare state; for him, the challenge is how to upscale "militant particularisms" into a hegemonic project (see Sheppard 2006). Others criticize localist actions for their disregard of state power and an abandonment of "strategic" thinking (Fuentes-Ramírez 2014). Although critical Marxists increasingly recognize the importance of combining "interstitial" with "ruptural" strategies (Wright 2010), their theorizations remain abstract as they are usually situated outside the "real movement" of conflict and struggle. 
The literature on alternatives is divided between "believers" and "skeptics" (Hillebrand and Zademach 2014). The former are interested in how alternative economies build a politics of possibilities; the latter on their limits within capitalism. Our starting premise is that this division is intellectually and politically unproductive. On the one hand, the lack of engagement on the part of the skeptics with the question of the origins and dynamics of alternative economies has led to an under-theorization of the conjunctures of their development. For instance, Castells et al. (2012), inspired by a diverse economies framework, argue that the crisis led people to engage more and more in non-capitalist economies. A new economic culture forms as a result, which in turn drives to a "direct political conflict whose outcome will determine the world we will live in" (Conill et al. 2012:245). De Angelis (2012:15-16), from an autonomist perspective, argues that the "explosion of the middle-class" with the crisis instigates the "explosion of alternatives as dominant forms or modes of production ..., a necessary element of [a] process of radical transformation". For Holloway (2010:151), the crisis is a sign of liberation as it results from "a failure to subordinate ourselves to the degree that capital demands from us". These accounts posit an automatic link between economic crisis and the rise of alternatives; in turn the destiny of these alternatives to confront (and supersede) capitalism is taken for granted. But as we will argue, the emergence of alternative economies is far from a spontaneous and cumulative reaction to crisis; and their transformative character is far from given.

On the other hand, the overemphasis of skeptical scholars on "limits" underplays the socio-spatial dynamics of alternative economies, and overlooks their potential insertion in activist strategies with a transformative horizon beyond a politics of difference or autonomy. This is unhelpful: in places like Greece or Spain alternative economies proliferate and inspire; they demand to be assessed properly.

We are not the first to recognize the need to go beyond this division between believers and skeptics. We share Fickey and Hanrahan's (2014:395) call to "identify and document potentially emancipatory forms" for their "subversive potential", namely by considering the gendered and other powered arrangements of diverse economies (Jonas 2014; Lawson 2005; North 2005; Samers 2005), and their contingency to historical-geographical contexts (Jonas 2010). However, the subversive potential of alternatives alone may not be enough. As Bensaïd (2009:151, our translation) argues, a politics of "subversion is subordinate to what it resists and fights against; this is the weakness of the stoic rhetoric of resistance, despite its determination not to surrender to the order of things". It is in Bensaïd's work that we find a framework that allows the development of a critical theoretical lens from which to both analyze and explain alternative economies, assessing their transformative potential.

The next section of our paper argues that from Bensaïd's perspective the core analytical question concerns the activist strategies and specific conjunctures that lead to the emergence and development of alternative economies. Transformative are those activist strategies that have a horizon to supersede social relations of domination through a politics of conflict and social struggle, seeking political alliances and convergence, not simply affinity. Such projects put at the forefront the issue of challenging, and also transforming, the state. The point is not whether such 
projects face limits or not (of course they do), but how they confront and respond to concrete barriers.

The third section presents methods and case studies: two alternative food economies in Biscay (a province of the Basque Country, Spain) and Greece. The fourth section applies Bensaïd's framework explaining the activist strategies and specific conjunctures behind the two alternative economies, and how they have responded to political-economic and institutional barriers. The paper concludes with ways to look at why and how alternative economies emerge and develop and how to think their transformative potential.

\section{Politics as the Art of Strategy}

Daniel Bensaïd (1946-2010) devoted his oeuvre to the question of politics and social emancipation from capitalism. He was a critical Marxist who rejected determinist, voluntarist and incrementalist understandings of social change (Bensaïd 2002, 2007, 2009). For him, economic conditions such as a crisis will not spontaneously (nor through spreading radical ideas or spectacular actions) turn the working class into a political subject and force. Social change, he argued, also would not be achieved by the passive accumulation of social forces and incremental changes, either through institutional politics or its mirror image of an anti-state politics. For Bensaïd social change is "determined conjointly by struggle and necessity" (2002:2); necessity to overcome capitalism, but with a struggle contingent on historically produced conditions and conjunctures. Between necessity and contingency-between the possible and the not yet here-intervene politics; politics as "strategy and error" (2002:5) for expanding possibility. Politics for Bensaïd is the art of uncovering historical possibilities, conflictual moments, weak knots, and favorable situations, acknowledging potential limits and barriers, to theorize and intervene strategically with a horizon of changing the balance of social forces and seize power.

The question is precisely how the exploited and oppressed may become a social and political force. For Bensaïd there is no automatic translation of social classes into political subjects. It is from the experience of conflict and struggle that the "knowledge of the reciprocal relations between classes is acquired" (2007:150). Politics thus is not to be levied in "outside" spaces, but from the inner contradictions of capitalism. The moment of rupture with ruling power is not reducible to the event of seizing state power. It results from sustained conflict and struggle in all social spheres as antagonisms of class, gender or race are mutually constitutive. And from these processes "a general crisis of the reciprocal relations between all the classes in society" might emerge and make rupture possible (2007:150).

State power is always at stake in politics. The state is an arena of condensation of social antagonisms. It works through "institutions and mechanisms that are ideological, material and armed" (Bensaïd 2009:227, our translation). It is imperative to struggle for the state, but without an illusion that reforms can radically change society. This also depends on deep processes of social radicalization and the emergence of new forms of power that confront and dissolve the old social structures. Thus the importance to enact "procedural revolutions in the ways of living before 
and after taking political power" (2009:158, our translation). Bensaïd hence avoids fusing the social into the political; both have relative autonomy. He also rejects the division between reform and revolution. Reforms are not in themselves reformist or revolutionary. It depends "on their purpose and the social dynamics they help to create, if they allow to expand social struggles and political consciousness or to detour them" (2009:201, our translation).

Transformative politics for Bensaïd is about extending self-organization and struggle in all realms of life with a horizon of changing the balance of forces, envisioning their condensation into a hegemonic project putting into question political power and its institutional forms. And this without separating the social from the political, i.e. avoiding the illusion that resistances can bring systemic change without confronting the political power of elites. Confronting such forces requires strategic thinking and action, self-organization and the condensation of positions. The expansion of struggles and their convergence is not spontaneous, and cannot be determined a priori.

From Bensaïd's perspective there is no reason why an economic crisis should lead to a new economic culture or social fabric. There is nothing that automatically connects alternative economies to political subjects and conflict, to social transformation. Contra skeptics also, the point is not merely to identify barriers and risks of fragmentation, co-optation, and particularism. The question is how activist projects in concrete historical-geographical contexts develop alternative economies as part of their transformative strategies, how they respond to and deal with difficulties, and whether ultimately they contribute to extend social struggles and confront the capital-state nexus. The interesting analytical question in other words is how activist projects strategize their struggle in particular conjunctures and respond to barriers.

Bensaïd provides an analytical and normative framework. Analytically, he invites a consideration of the activist projects in which alternative economies develop, considering their transformational views and how they strategize their struggle within particular historical-geographical conjunctures. Projects that attempt only to secure space at the interstices of capitalism or expand acritical difference are unlikely to be transformative. Projects that seek to overcome social relations of domination and orient their strategies to extend social struggles and confront the capital-state nexus, while searching for political convergences that overcome fragmentation are relevant to transformative politics.

\section{Case Studies and Methods}

We ground these issues on two alternative food economies in countries at the maelstrom of the current economic crisis, Spain and Greece. In these countries the crisis has catalyzed the growth of alternative economies, especially in food production and distribution. In the literature on alternative food networks, one finds believers that place practical alternatives and local progressive reforms as ways to imagine and create just and sustainable food systems (Goodman et al. 2011) and more skeptics like Guthman (2008:1171), who investigating agro-food activism in California, finds that oppositional forms "seem to produce and reproduce neoliberal forms, 
spaces of governance, and mentalities". Following Constance et al. (2014:6) we want to understand better the barriers and opportunities for alternatives to "act as emancipatory agents to transform the agrifood system".

Between 2008 and 2013, Greece lost almost 1 million jobs, wages decreasing on average by $38 \%$ (S4A 2015). In 2013, 28\% of Greeks reported that there were times in the last year that they did not have enough money to buy food for their families, up from 8\% in 2007 (Dugan and Wendt 2014). In Spain, unemployment more than doubled between 2008 and 2014. Almost two million Spaniards depend on food banks (El País 2013). In Greece, "the economic crisis has led to the reinstatement of a 'new rurality', in which agriculture seems to attract new attention" (Kasimis and Papadopoulos 2013:287). In Spain, the press and small-farmers organizations often make bold claims about a "return to the land" (El País 2014). Compared with Greece, Spain had a "new peasant" movement before the crisis (Montllor 2013) and a history of radical alternatives in the countryside (Breitbart 1978). In Greece the "grassroots social solidarity movement is one of the most important developments and forms of resistance and people's self-organization to emerge in the last four years" (S4A 2015), whereas in Spain the solidarity economy movement was already consolidated.

The first case study, in the Basque province of Biscay, focuses on the new agroecological "peasants" supported by Euskal Herriko Nekazarien Elkartasuna (EHNEBizkaia). EHNE-Bizkaia started as a union of small farmers in 1976 and evolved into a food sovereignty activist organization, member of La Via Campesina. It currently employs 20 people distributed in four offices. Its 800 members pay an annual fee, receive technical services, elect its board, and determine its politics. Since 2007 EHNE-Bizkaia supports new baserritarras ("peasants" in Basque) with training in agroecology and a network of community-supported agriculture-the "Red Nekasarea". Only $1 \%$ of the Basque active population works in agriculture (EUSTAT 2014). At the onset of the crisis the number of people applying for EHNE-Bizkaia's training increased, from 30 to 40 in 2010 to 150 to 200 in 2013, with a socio-demographic shift from mostly women with an agrarian vocation to ex-industrial, male workers (EHNE-Bizkaia 2012). From 2008 to 2012, 50 new people settled as baserritarras with their support.

The farms of baserritarras are small sized, frequently less than 1 hectare. Usually the baserritarra lives in or near the farm-holding; short distances to the city allow some to commute. Baserritarras do multi-cropping for self-consumption and direct sale; they practice a low-input eco-farming agriculture based on agroecology. Often family members have non-farm jobs, while diverse baserritarras share the farm. We call them "peasants" because they endorse claims of "peasantness" and practice farming grounded in nature and local communities (Ploeg 2008).

Red Nekasarea includes 80 baserritarras and 700 households; the latter are divided into consumer groups of no more than 30 households (EHNE-Bizkaia 2012). Each group is supplied with vegetables by a single baserritarra, who has to collect the other products and deliver the weekly basket at a pre-fixed place. The food basket includes vegetables, meat, milk, eggs, and pasta. Red Nekasarea's internal regulation sets technical and social norms: environmental requirements, working conditions, and the expected income of baserritarras. Consumers assume a one- 
year contract at a fixed price after a three-month trial. The producer determines the contents of the baskets depending on season. The price is set by baserritarras given the costs of production, and agreed with the consumer groups directly. Baserritarras periodically meet at the county level, with the participation of EHNEBizkaia.

The second case study focuses on the "no-middlemen" distributions in Greece. Volunteer-based groups there organize distributions where farmers sell their products directly at pre-agreed prices. In by-passing the intermediaries, consumers have access to quality products with prices $20-50 \%$ lower than in retail markets, whereas farmers are paid better and on the spot, which is not the case when merchants mediate. Producers are selected according to quality, price and proximity. Typically consumers have to pre-order minimum quantities by internet or phone. Most groups require farmers to give for free $2-5 \%$ of their goods to impoverished families.

The no-middlemen initiatives began in 2012 after farmers distributed potatoes for free in the central streets of Thessaloniki. This was a protest against low prices and merchants' tactic to reject part of the produce to control final prices. While farmers were in difficulty, food prices "have remained relatively high despite the recession" (Skordili 2013:136). A civic group from Katerini, in Central Greece, organized then direct sales of potatoes at low cost. Similar initiatives spread across Greece, especially in the big cities of Athens and Thessaloniki. The deliveries diversified beyond potatoes and covered most basic needs with products like flour, olive oil, legumes, honey, and cheese. In 2014 there were 45 no-middlemen groups, 26 in Athens; 5000 tons of food was distributed from 2012 to 2014 (S4A 2015).

Groups self-organize with open assemblies, and decisions are consensus based. Each group has on average 19 core activists and 29 volunteers that help in distributions (S4A 2015). Most groups also organize other solidarity actions in the neighborhood. There is no central coordination of the initiatives, though groups often coordinate informally at the regional level. Some groups, mostly in Athens, receive logistical support from "Solidarity For All", a structure set up by the political party of SYRIZA, and funded by the salaries of its parliamentarians. Five national events were organized between 2012 and 2015, three in Katerini and two in Athens.

A typical distribution in Central Greece offers one to ten non-perishable products, each provided by a single producer. Only professional farmers participate, and they issue invoices. Information about deliveries is spread through the internet and flyers. Consumers have to pre-order a minimum quantity. On the day, consumers pay to the coordinating "secretariat" and collect the items from the truck of the producer. Dozens of volunteers dressed with traffic vests guide producers and consumers. Distributions take place in parking lots in peripheral areas, and have municipal permits to occupy the public space. In Thessaloniki instead, typically there are no pre-orders, and consumers pay farmers directly. Distributions offer 20 to 40 products, including fresh vegetables and fruits. This is facilitated by Thessaloniki being at the middle of an agricultural plain. Groups there work only with small farmers, with the same product being supplied by several producers. Non-professional producers can participate and there is no requirement for 
invoices. Distributions take place in central streets. They rarely have municipal permits and often face problems with tax auditors or the police. Athens' distributions follow a model in-between these two: groups usually work with pre-orders, have a high number of products and farmers, and give preference to small farmers. Distributions in Athens and Thessaloniki involve political information in leaflets, banners, leftist music and slogans. Debates may be organized on issues such as solidarity, austerity, or neo-nazism. Most groups are involved in other political actions in their regions, e.g. struggles against the privatization of water, electricity taxes or road tolls.

The network of baserritarras signals an alternative model of producing food; the no-middlemen initiatives an alternative model of distributing food. These food economies are "alternative" because they defy conventional markets based in generalized commodity production for maximum profit. They focus on social needs and promote solidarity, reciprocity, and not-for-profit production.

\section{Methodology}

We have followed a case study approach as it allows an in-depth exploration of the complex relationships, processes, meanings and nuances involved in real-life social phenomena such as alternative economies, embedded in context (Snow and Trom 2002). This entails an understanding of people's motives for action, with consideration of their explanatory power; hence the use of qualitative methodologies and the continuous feedback between fieldwork and research design (Della Porta and Keating 2008).

The first author conducted interviews, observant participation, and collected secondary material from the two cases. Between October and December 2013 she worked as a volunteer in EHNE-Bizkaia. She informed EHNE-Bizkaia about the objectives of her research, and the agreement was that she produced a report summarizing the findings from her interviews. She attended three training sessions in agroecology, participated in four local meetings of baserritarras of Red Nekasarea, visited farm-holdings, attended two international seminars where EHNE-Bizkaia participated, followed the visit of a La Via Campesina delegation from Latin America, and worked in EHNE's stand in two farmers markets. She interviewed 26 new baserritarras trained in agroecology in 2012 and 2013 or being part of Red Nekasarea, asking about motivations, challenges, meanings of agroecology and food sovereignty, while collecting data on land, production, and working time. In Greece, a preliminary research period in Athens in February 2014 included conversations with key informants: university professors, researchers, food cooperatives, farmers and activists from two no-middlemen groups, and Solidarity For All. Between April and June 2014, 23 core activists were interviewed from no-middlemen groups in Athens (12), Thessaloniki (seven) and Central Greece (four). Questions concerned motivations, organizational issues, and prospects. The first author also attended a national meeting of the no-middlemen groups (in February 2014, in Katerini), participated in the assemblies of two groups in Athens, and observed three distributions in Central Greece, one in Thessaloniki, and four in Athens. 
The focus on qualitative methods required openness and flexibility, as well as reflexivity on the subjectivity of the researcher (England 1994). Language was partly a barrier. In the Basque Country, Spanish was used-a language perceived by some as colonial. Speaking Spanish with activists and new peasants risked a distancing (less so though when used by a foreigner). In Greece, interviews were held in English or with an interpreter. Distance was often overcome by the similar history and culture shared among Southern Europeans. The first author was an "outsider" not involved in the movements. She may have missed nuances of personalities, political positions and events, or historical background and context. On the other hand, she benefited from a more detached, and critical when needed, assessment of the two projects. This is a situated research and there is no claim to impartiality. The researcher came to the field with her own theoryshaped perspectives and beliefs. Perhaps the short duration of fieldwork did not allow empirical reality to challenge them as much as it could have. Nonetheless, research questions evolved considerably over the fieldwork. Empirical research started with a very broad political ecology framework. As empirical observations accumulated and regularities were discerned, there was a choice to unite and give meaning to the material through Bensaïd's theory. In that sense, this is situated, grounded research.

\section{Alternative Economies in the Basque Country and Greece (1): Where did the Alternatives Come From and What is Their Horizon?}

Here we apply Bensaïd's analytics. We first investigate the activist projects and conjunctures of emergence of the two alternative economies and ask what is their strategy and horizon of struggle and whether they go beyond a politics of "cracks". Next we focus on the barriers they face, and how they respond to them; in particular we are interested in whether they attempt to organize to challenge state power, and if yes, how.

The crisis did act as a catalyst in the decisions of many individuals to shift to agroecological agriculture in Biscay or to organize to bypass middlemen in Greece. These dynamics, however, did not appear out of nowhere, and the alternatives are not exhausted in responding to the unemployment or food poverty generated by the crisis. Both built on activist projects with a transformative horizon and an ability to strategize struggle within specific conjunctures. The goals of these projects are collective and political, and they seek transformative change through a politics of conflict and social struggle.

\section{The Origins and Politics of Alternative Food Economies in Biscay EHNE-Bizkaia is a small farmers' union with a long history of political activism. By the late 1990s it was clear that small farmers' interests could not be defended "without talking of the model of production and the model of development one as- pires to", Unzalu, ${ }^{1}$ coordinator of EHNE-Bizkaia, remembers. The adoption of food}


sovereignty as a political framework was informed by international debates put forward by La Via Campesina, but mainly by neoliberal policies which aggravated the impacts of agrarian capitalism on the livelihoods of small farmers, and an acceleration of the uncontrolled urbanization of agricultural land. These tendencies called for a problematization of the model of agriculture and a proposal of alternatives.

EHNE-Bizkaia hence started promoting "re-peasantization", i.e. reducing the dependence of small farmers on capitalist markets by a shift to agroecological production, alternative food networks (Red Nekasarea) and re-localization. This was not merely a survivalist reaction by small farmers. The intention was to politicize agrofood issues, attract new young baserritarras to face an increasingly aged sector, and generate a dynamics of social mobilization, while experimenting and advancing a proposal on how the agro-food system can be organized differently-that of "food sovereignty". This new praxis of developing alternative economies had the ambition to construct a broader social movement of baserritarras for food sovereignty through alliances with consumers, trade unions, social movements, and political forces. In "Euskal Herria we can have 4,000 producers in the core base of this movement, and from 4,000 go up to 8,000, 10,000 people that converge and develop it", Unzalu argues. This broad movement arose in 2011 under the name of Etxalde. From a Bensaïdian lens, re-peasantization is a strategy through which the sector is rejuvenated and popular classes are politicized and mobilized around a political project of food sovereignty.

This shift of strategy had practical implications. To promote agroecology as the pathway for restructuring agriculture, EHNE-Bizkaia stopped training farmers in conventional farming. Training also became a tool through which to attract new young baserritarras, as well as reach out to society with diversified offers open to anyone interested. Red Nekasarea supported both of these objectives.

The baserritarras we interviewed said they were attracted to agriculture or saw it as a feasible option after attending debates or training sessions by EHNE-Bizkaia. The broader crisis context played a role in their decision to become farmers, but it was one factor among others. The availability of (almost) free training in agroecology was appealing, many claimed. Technical training is vital for launching a new farm. Agroecology was also attractive, we were told, because compared with the high investment required for entering conventional farming, it depends very little on external inputs such as seeds, fertilizers, or technology. Red Nekasarea protects new baserritarras from market uncertainties and middlemen, ensuring that they can start gradually, plan their production, and have a regular income. Consumers in the network pay a fixed amount per year, and in this way the risks of production are shared and the initial costs of investment secured. Bittor, who started in 2011, says: "It was hard at the beginning. We did pretty bad financially, our produce was pathetic. But we went there [to Red Nekasarea] and people said 'you are starting, relax, and go ahead"'.

EHNE-Bizkaia promotes cooperation between baserritarras during the training, and later through online communication tools. This, many told us, helps them face insecurities and create a mutual-aid environment.

Unlike common depictions in the Spanish and international press of a spontaneous "return to the land" move of youth pushed by the crisis, what we found 
in Biscay was a well strategized and supported move with clear political purposes.

The objective of EHNE-Bizkaia is not to just build practical alternatives through which to show that another agro-food model is possible and better. The aim is to politicize agro-food issues through the clash of models and create a broad social movement fighting for food sovereignty. Hence the strong ideological discourse on alternatives. Unai, who is responsible for training, explains: "If for us food is a right ... we have to explain how the system works and the alternatives we have and want".

EHNE-Bizkaia's ideological discourse unpacks the political-economic relations structuring the agro-food system, calling for its radical transformation. When then new baserritarras engage in alternative economies they understand these as embedded in a political project with transformational ambitions. EHNE-Bizkaia also wants the new baserritarras to realize that the aim is to insert alternative projects within a dynamic of transformation that implies collective action and social mobilization. This explains, for example, the understanding of "peasantness" as a political claim, rather than a fixed economic condition. More than half of EHNE-Bizkaia's members actually are baserritarras practicing conventional farming who actively support the political project of food sovereignty and agroecology. As Unzalu explains, there is no division between conventional and "alternative" producers:

The conflict is between models of production, not the people in different models ... The organization is not here to defend the model that each is practicing; it is here for the whole sector ... It is political powers that instigate the confrontation between people, instead of models.

EHNE-Bizkaia's strategy of re-peasantization entailed the development of alternatives of production and distribution, together with a strong ideological work. The purpose is to create a dynamics of self-organization and collective action fighting for food sovereignty (Etxalde), rather than to build economic difference or antagonistic autonomous spaces. Bensaïd's framework helps to uncover these dynamics.

\section{The Origins and Politics of the No-Middlemen Initiatives in Greece}

The problem of "middlemen" has been a high-profile political question in Greece with the transformation of the food sector into "an arena of oligopolistic competition" (Kasimis and Papadopoulos 2013:288). As an orange producer from Piraeus' group explains:

Greece has one of the worst supply-chain circuits in Europe. There are three main problems with merchants: low prices, frequently lower than the farmer costs; they do not pay regularly, creating indebtedness; there is no standard agreement setting the rules between farmers and middlemen.

Food poverty in Greece is both "the result of inadequate household income, as well of limited choices of sourcing food in the city due to food retail sector consolidation. Corporate retailers have been criticized for greed and unethical pricing 
practices" (Skordili 2013:129). The inflation of food prices during a recession suggests unwarranted middlemen profiteering. As Panagiota, a young activist from Kalamaria, Thessaloniki, explains:

It was very obvious that something was very wrong. With the crisis and lower incomes, prices did not go down, yet farmers were in difficulties ... In the central market they throw food away to keep the prices high ... With our initiatives the price cannot be too low for farmers so that they can continue to produce ... If we don't strengthen the Greek production, prices will go up.

The no-middlemen distributions did emerge within the crisis to face a growing situation of food poverty. But they do it by tackling some of the structural factors behind it, and have broader political objectives. Crucially, the no-middlemen initiatives are part of a larger grassroots solidarity movement triggered by "the multifarious struggles of Greek society against the Troika and the bailout programs, especially the occupation of the squares in the summer of 2011" (S4A 2015). Many no-middlemen groups from Thessaloniki and Athens arose out of post-squares neighborhood assemblies, whilst others were inspired by them or the broader anti-austerity environment. Olga, a young precarious worker from Thessaloniki, explains that her group was created:

three years ago to campaign against the additional property tax included in the electricity bill; when this struggle declined, we thought of other actions to resist austerity and built up solidarity with the ones affected. We decided to start the food distributions.

Solidarity is a crucial strategic objective of the no-middlemen groups. A logic of mutual-aid intends to "give hope", "help people to self-organize", and "pass from the I to the We", as different activists tellingly put it. The objective is to provide the material and subjective conditions so that people mobilize against the politics of austerity and reflect on "what kind of society and democracy they want to claim", as Thanos, an unemployed activist from Toumba, Thessaloniki, explains.

For Eva, a middle-aged lawyer from Thermaikos, Thessaloniki, the food distributions were not only about responding to food poverty and farmers' problems, but:

also a good chance for us to speak about the crisis, the government that led us to the crisis, about Troika and the EU that oblige countries to be in crisis. We wanted people to get out of their houses, to come with us, and rise up.

Food distributions are also a "symbolic battlefield" around notions of "solidarity" (Chatzidakis 2014). The conservative (at the time) government, private-capital, the church, and the neo-nazi party "Golden Dawn" are holding their own food distributions based on philanthropy, charity, entrepreneurship, or xenophobia (the neo-nazis serve "only Greeks"). The groups we studied instead make much of their insistence on no monetary transactions, equal relations, reciprocity, and horizontal democracy.

Political inclinations differ among groups. In Athens, there is a stronger presence of activists affiliated to radical left political parties. In Thessaloniki, there are more 
activists that are autonomist oriented. In Central Greece, activists insist on their "civil society" character. Nonetheless, all share the goal of defeating the politics of austerity. Kostas from Piraeus thinks that "the difference between the groups is organizational, not political. There are different experiences but our main goal is the same".

For many in the no-middlemen, the control of the agro-food system is central in a strategy of toppling the neoliberal austerity agenda. As one activist at the national meeting tellingly puts it: "We cannot achieve political uprising in a country that does not produce enough food". While the struggle against austerity is crucial, the actions of the groups are envisioned as setting a path towards a radical transformation of the agro-food system and the whole of the economy. Like their counterparts in the Basque Country, the no-middlemen initiatives aim to reconstruct and reorganize a non-corporate agricultural and food sector. As Thanos says: "one of our aims is to contribute to reconstructing production through the solidarity economy, and to encourage small farmers to cooperate between them and sell outside traders."

From a Bensaïd-inspired perspective, no-middlemen distributions grounded in solidarity are part of a strategy to resist austerity, while promoting learning processes on how to reorganize the agro-food system. More than building difference or autonomy, activists organize distributions as a tool to politicize the crisis and mobilize the popular classes to fight austerity and claim alternative futures.

\section{Alternative Economies in the Basque Country and Greece (2): Responding to Barriers by Extending Struggle and Confronting the State}

In the case of the Basque Country, the main barriers for new peasants are access to land and the viability of their ventures. For the no-middlemen distributions the main problems are repression from the authorities, co-optation and fatigue of activists. Both respond with a politics of protest and political demands, while they seek to transform the state itself.

\section{Political-Economic Barriers: Private Property, Competition and the State}

In Biscay $75 \%$ of the population lives in urban areas. Only $30 \%$ of the territory is designated for agriculture (Bizilur et al. 2015). Access to land is difficult because of high prices, urbanization pressures and private ownership (Youth Council of Euskadi 2010). Many owners are reluctant to sell or lease land to new farmers because they can get a higher price later for real estate. According to official statistics, the average price for a hectare of land in the Basque Country was 15,000 Euros in 2007 (MAGRAMA 2014), but it can go up to and over 100,000 Euros, which was the price paid that same year by a baserritarra we interviewed. All interviewees, except those who had family property, argued that access to land "was the hardest part" of their experience. 
Economic viability is another core concern. New peasants aim to secure affordable prices so that they "can feed the workers, not elites". This is also an important objective of Red Nekasarea. However, selling at social prices may not be viable, given the high costs of land and food transport and the decline of consumers' purchasing power due to the effects of crisis and austerity. Wages, transportation costs, or mortgage interest rates are all factors that determine the viability of farms, determined by a capitalist economy that is beyond the influence of small farmers. As Benate, an ex-precarious media worker who is now a baserritarra, puts it: "like it or not, we live in this world. We still have costs even if we earn a living differently and have a different lifestyle, with lower expenses". To keep the food price low, baserritarras try to reduce costs by increasing self-provision and their hours of work, or devalue their own payment. This might be difficult in an already labor-intensive farming model, in which "the effort required is huge ... and you put a lot of hours that no one will pay", as Maite, daughter of ex-baserritarras, puts it.

In Greece, the main obstacle was the authorities' repression. No-middlemen groups in Athens and Thessaloniki could not obtain municipal permits to occupy public space. The police often intervened and ended distributions. Athanasia, an activist in Maroussi, Athens, explains that in January 2014:

the mayor of the city sent the police and tax auditors and they fined producers 1000 Euros each. They asked for their papers and they were legal. They asked for invoices and they had them. They fined them because there was no permit to occupy the place. But the market was not in the middle of the street or in any central zone. It was in a dirty, poorly located place that no one uses.

A Parliament law passed by the conservative government in May 2014 (the "2014 law") aggravated the situation: it forbids itinerant trade near shops with similar products and in municipalities with more than 3000 inhabitants; requires that stationary markets are proposed and approved by municipal or regional authorities; adds obstacles to farmers who want to obtain permit to sell directly; and increases the fines and includes an imprisonment penalty for those who prevent controls from the authorities or have no permit.

Another threat is the co-optation of initiatives by conservative mayors and private capital. As Alekos from Vironas, Athens, explains, the no-middlemen distributions organized by the mayor in his neighborhood "do not create a different logic between the farmer and the consumer; it is only about low prices and the reelection of the mayor". In the last years, several strictly commercial no-middlemen initiatives have popped up (Ekathimerini 2014).

The activists we talked to also complained of fatigue. The sustained engagement of farmers and consumers in the solidarity groups has proven difficult. Nikos, a university professor active in Thermi, Thessaloniki, concedes that: "by now we are tired and disappointed because producers are tricky and consumers are passive". Fatigue relates also to the personal conditions of activists. Most of them are unemployed and suffer from the effects of austerity policies. Furthermore, they are aware that their voluntary unpaid work may substitute that of middlemen merchants, or contribute to shifting to society the burden of dealing with the effects of austerity. 


\section{Responding to Barriers: Re-organizing and Scaling Up Institutional Battles}

The obstacles posed by the capital-state nexus on alternative economies are considerable, and may become fatal. However, from a Bensaïdian perspective, the question is how activist projects respond to such barriers.

EHNE-Bizkaia helps new baserritarras find plots of land, and often intermediates with ex-baserritarras to facilitate deals. But this is not enough; structural barriers call for struggle to change structures. Land policy has been at the center of the political activism of the organization. EHNE-Bizkaia has contested the model of development for the Basque Country, and its disregard for agro-food issues. A "historical battle" was won when the regional government approved its proposal to set up a public land fund to facilitate farmers' access to land. This fund, active since 2010, is composed of public land and out-of-use private land rented at non-speculative prices to farmers for a minimum of five years (with priority to young farmers). Unzalu accepts that this is more of an ideological victory than an effective solution to the land problem. However, its significance is that it "challenges the primacy of private property". For EHNE-Bizkaia authorities should recognize agricultural land as an "irreplaceable value of production", protect it from urbanization, and guarantee its social function-that of food production that covers social needs. The state therefore is not left aside, but a central locus of action for EHNE-Bizkaia.

Food prices and farm viability are a major concern for EHNE-Bizkaia. There is awareness that there is a limit in pursuing food sovereignty within the contours of the market. EHNE-Bizkaia calls for the direct intervention of authorities to redraw the agro-food system away from the corporate model. Unzalu argues for the "need to re-arrange the entire agrifood system and recover the public function [of the state]. Why should the 'public' be limited to regulate and give subsidies? Why not intervene, organize and control?"

This struggle for reforms, however, is not an end in itself; in a Bensaïdian fashion, it is conceived as a "strategic tool to dispute spaces and proposals" (Bizilur et al. 2015:3) and extend social mobilization. Unlike Greece, nonetheless there are few attempts, other than discursive, to combine food sovereignty struggles with anti-austerity struggles. Perhaps there is too much emphasis on the building of alternatives and this does not allow a re-alignment of political practice at the current conjuncture.

In Greece, different groups respond differently to the authorities, and this is a major point of divergence within the "movement". The groups of Central Greece are more "legalistic". Groups there organize pre-orders so that distributions are qualified as e-commerce, a grey area in the law. They tend to collaborate with conservative mayors to obtain permits, staying away from central streets. The groups of Thessaloniki and Athens instead refuse to cooperate with conservative mayors as they see them as complicit in applying austerity. They insist that they have to resist attacks from the authorities by gaining popular support for the distributions; the politicization of actions is thus fundamental. The groups of Athens are more careful in how they handle the confrontation though: they always ask for permission (which is often denied), usually work with professional farmers who can issue tax 
invoices, and often they too organize pre-orders and place distributions outside central streets. Most of Thessaloniki's groups refuse to do any of this and were heavily targeted by authorities with the result that many groups and distributions there stopped.

Despite differences, all groups agree that the law has to change if distributions are to continue and grow, and especially if the agro-food system is to change structurally. Many groups are discussing internally and collectively changes to the legal framework, while voicing publicly their opposition to the 2014 law. Many activists hoped that a victory of left-wing SYRIZA in the January 2015 elections could bring institutional changes that would support their initiatives. Athanasia, from Maroussi, Athens, speaks for many: "before the new law I was optimistic. With this government there is no optimism; with another government there would be a boost of solidarity, but this government is breaking, destroying everything". (Despite SYRIZA's rise to power, the 2014 law has not changed at the time of writing this article.)

Many groups considered it important to change power in their municipalities. Solidarity groups as such did not participate in the last local elections of June 2014, though some of its members in Athens and Thessaloniki took part in SYRIZA-backed or independent candidacies. Most of our interviewees are also clear that they want autonomy from political parties and state institutions so as to maintain a social movement character and keep struggling for deeper social change, including of the state itself. As Kostas from Piraeus explains:

if with the municipal elections the panorama changes, the movement has to discuss how to keep its independence and work with municipalities of the Left, but not to work for them and kill the movement ... We also don't want to be absorbed by the government [in case SYRIZA wins], but to be part of the struggle for another economy against the capital. The state should change towards the solidarity economy.

Like in Biscay, the state is not left aside. Many no-middlemen groups make adjustments to the distributions so that these are not stopped or co-opted, while attempting to advance policy reforms. In a process akin to Bensaïd's understanding of politics, this is done with the prospect of extending social struggle and building alternative forms of social power. Groups hence develop tools to counter some of the difficulties faced in organizing and mobilizing the popular classes.

For instance, groups in Athens and Thessaloniki increasingly organize the distributions as festivities to promote the involvement of farmers and consumers other than in the day of the distributions. In Kipseli, Athens, the group organizes a collective soup on the occasion, and in Zografou, Athens, activists organize activities for children. The organization of the groups through open assemblies is also a way to involve more people in the long-term running of the groups; some groups in Thessaloniki organize assemblies on the day of the distribution to attract more participants. Besides the food distributions, the groups also organize other solidarity actions like free lessons or social clinics, or regularly promote debates, movie projections, or gatherings in the neighborhood.

The promotion of self-organization and politicized spaces around "solidarity" is very important for the groups. As Kostas explains: "all of us are leftist and we do 
not want to act like a salesman or become a salesman; it is important that people understand this, and we try to convince them of our solidarity purpose". Solidarity is to be understood as oppositional to philanthropy and charity. Activists know that "they are covering a lacuna of the state", but, as Nikos from Thermi, Thessaloniki, argues: "we are not replacing the state. We have a political agenda, we set issues in the agenda and we force the state to react".

There is currently a debate within the groups about the evolution of the distributions into "a network of linked co-operatives" (Rakopoulos 2014:206) that would allow the distributions to go beyond the role of safety nets based on voluntary labor. Cooperatives could create permanent spaces for farmers and consumers, provide jobs and potentiate solidarity in economic relations, but come with their own risks to the groups' purpose of extending social struggle and forcing changes from above that are beyond the scope of this paper. SYRIZA's surrender to the Troika's program of austerity has left no prospects for a statebacked re-conversion of the economy along solidarity lines in which the groups could be active participants in a restructuring from below, including a transformation of the state. This situation poses new challenges for activists and their horizon of struggle.

\section{Conclusions}

How and why do alternative economies emerge and develop in times of economic crisis? Alternative economies, or at least the two cases that we studied, are not just the direct outcome of the social hardship of crisis. They are a product of activist strategies developed within specific conjunctures. In the Basque Country, an already existing movement of small farmers for food sovereignty facilitates the move of non-farmers to land and agroecological farming, a move with reinvigorated interest under the crisis. In the case of Greece, a grassroots solidarity food network was catalyzed by anti-austerity mass mobilizations and the speculative behavior of food intermediaries.

Issues of space, place and scale are relevant for both projects. ENHE-Bizkaia links explicitly food sovereignty with the question of control over the territory, adopting a relational perspective of scale in which the local, national and global co-determine each other. The food distributions in Greece are local and regional in scope, but are envisioned as part of a re-localization of the Greek economy and territory governance. These are relevant fields and areas for further research which are outside the scope of this paper. We did not go into as much detail as we would have liked in the territorial or historical-geographical character of the projects, and their attempts to (re)construct scale. This should definitely be part of future research on alternative economies. Our contribution here is to offer to the reader a new analytical and normative lens to look at alternative economies beyond the stale dichotomy of celebration or skepticism.

This paper, inspired by Bensaïd's political theory, illustrates how alternative economies can be central in transformative strategies and reciprocal to more classic forms of protest-type politics. The projects we studied play an important role in politicizing the crisis, the economy, and the agro-food system, as well as in extending 
conflict and social struggle, and in offering views of possible economic alternatives. In the Basque Country, "food sovereignty" is the strategic idea and practice for an alternative model of development that challenges established land and power relations across the countryside and the city. In Greece, a praxis of "solidarity" confronts neoliberalism and the politics of austerity. Both activist projects are keen to politicize their initiatives and activate subjects into collective action, as well to form strategic alliances with other social and political forces to upscale their struggle. They also seek to challenge the state, and not simply replace it or act in-between the market and the state. In this process they are aware of the need of changing the state itself and to amplify democracy from the grassroots. In that sense, we can argue that they are (always tentatively and potentially) transformative.

What are the implications of these findings for broader debates on alternative economies and social change? A diverse economy approach (Castells et al. 2012; Gibson-Graham 2006) may help to open individuals to critical thinking; however, it tends to essentialize alternatives when going against essentialized views of capitalism. Anti-power (Holloway 2010), counter-power (De Angelis 2012; Hardt and Negri 2009) and anarchist (Graeber 2002) frameworks highlight the positive capacity of individuals to resist the powers of capital but they fetishize resistance by refusing to deal with state power. Critics like Harvey (see Sheppard 2006), on the other, hand pay excessive attention to limits and not to the ways activist strategies may build transformative projects on the basis of developing alternative economies. Bensaïd's theory charters a different potential for alternative economies and in relation, a different way to look at them.

The two projects studied here did insert alternatives into oppositional strategies with a transformative horizon. They did go beyond fragments in resistance by embracing a social movement perspective engaged in a politics of strategic alliances, avoiding fragmentation. They did not intend to replace either the market or the state and they did not see the latter as a mere compliment to their action. Instead, they directly confront market forces and state power with the ambition to enact deeper changes in society and dissolve old social structures. They stepped out of the private sphere, the location of merely "doing differently", and acted in the public realm, the location par excellence of politics. This was not the result of a spontaneous reaction to the impacts of "the crisis". It was the outcome of strategic actions within the contingencies of struggle and its rhythms. These alternative economies are positioned within a transformative movement, but whether this transformation advances depends on whether activist projects effectively contribute to shift the balance of social forces.

\section{Acknowledgments}

This research was funded by the European Union's Seventh Framework Program (Marie Curie Actions) under grant agreement number 289374 (ENTITLE) and by Spain's Ministerio de Economia y Competitividad under the project SINALECO (PK612919). Kallis acknowledges support from a Leverhulme visiting professor grant. The authors are grateful to all who supported the fieldwork in Biscay and Greece, as well to Diego Andreucci, Melissa García Lamarca, Gustavo García, Santiago Gorostiza and three anonymous reviewers for helpful comments on previous versions of this paper. 


\section{Endnotes}

1 To protect the anonymity of our interviewees we use fictional names. We use real names only for members of ENHE-Bizkaia who had no problem revealing their identity.

\section{References}

$A B C$ (2013) El Neorruralismo va en aumento por la crisis. 14 September. http://www.abc.es/ economia/20130914/abci-neorruralismo-moda-201309141831.html (last accessed 20 March 2015)

Abramovich A and Vázquez G (2007) Experiencias de la Economía Social y Solidaria en la Argentina. Estudios fronterizos 8(15):121-145

Bensaïd D (2002) Marx For Our Times: Adventures and Misadventures of a Critique. London: Verso

Bensaïd D (2007) “Leaps! Leaps! Leaps!”. In S Kouvelakis, S Budgen and S Žižek (eds) Lenin Reloaded: Toward a Politics of Truth (pp 148-164). Durham: Duke University Press

Bensaïd D (2009) Elogio de la política profana. Madrid: Ediciones Península

Bizilur, EHNE-Bizkaia and Etxalde (2015) Sembrando soberanías para otros modelos de vida en Euskal Herria. Algunas propuestas para la construcción de políticas públicas locales desde la soberanía alimentaria. Basque Country: EHNE-Bizkaia

Breitbart M (1978) Anarchist decentralism in rural Spain, 1936-1939: The integration of community and environment. Antipode 10/11(3/1):83-98

Castells M, Caraça J and Cardoso G (2012) The cultures of the economic crisis: An introduction. In M Castells, J Caraça and G Cardoso (eds) Aftermath: The Cultures of the Economic Crisis (pp 1-17). Oxford: Oxford University Press

Chatzidakis A (2014) Athens as a failed city for consumption. The City at a Time of Crisis 4 May. http://crisis-scape.net/conference/item/187 (last accessed 23 August 2016)

Conill J, Castells M, Cardenas A and Servon L (2012) Beyond the crisis: The emergence of alternative economic practices. In M Castells, J Caraça and G Cardoso (eds) Aftermath: The Cultures of the Economic Crisis (pp 210-250). Oxford: Oxford University Press

Constance D, Renard M-C and Rivera-Ferre M (eds) (2014) Alternative Agrifood Movements: Patterns of Convergence and Divergence. Bingley: Emerald

De Angelis M (2012) Crisis, movements, and commons. Borderlands 11(2):1-22

Della Porta D and Keating M (eds) (2008) Approaches and Methodologies in the Social Sciences: A Pluralist Perspective. Cambridge: Cambridge University Press

Dugan A and Wendt N (2014) Families struggling to afford food in OECD countries. Gallup 30 May. http://www.gallup.com/poll/170795/families-struggling-afford-food-oecd-countries.aspx (last accessed 23 August 2016)

EHNE-Bizkaia (2012) Circuitos cortos de comercialización en Euskal Herria. Euskadi: Mundubat

Ekathimerini (2014) Farmers Republic going strong inside Greece and beyond. 16 October. http://www.ekathimerini.com/163897/article/ekathimerini/community/farmers-republicgoing-strong-inside-greece-and-beyond (last accessed 16 May 2015)

El País (2013) Hambre y Crisis. 12 September. http://blogs.elpais.com/metroscopia/2013/09/ hambre-y-crisis.html (last accessed 10 May 2015)

El País (2014) Papá, quiero ser agricultor. 11 February. http://sociedad.elpais.com/sociedad/ 2014/02/11/actualidad/1392151170_802474.html (last accessed 4 May 2015)

England K (1994) Getting personal: Reflexivity, positionality, and feminist research. The Professional Geographer 46(1):80-89

EUSTAT (2014) Población en relación con la actividad 2014. Basque Country: EUSTAT

Fickey A and Hanrahan K B (2014) Moving beyond Neverland: Reflecting upon the state of the diverse economies research program and the study of alternative economic spaces. ACME 13(2):394-403

Fuentes-Ramírez R R (2014) Marxist perspectives on $21^{\text {st }}$ century transition to socialism. Socialism and Democracy 28(1):123-142

Gibson-Graham J K (1996) The End of Capitalism (As We Knew It): A Feminist Critique of Political Economy. Minneapolis: University of Minnesota Press 
Gibson-Graham J K (2006) A Postcapitalist Politics. Minneapolis: University of Minnesota Press

Goodman D, DuPuis M and Goodman M (2011) Alternative Food Networks: Knowledge, Practice, and Politics. London: Routledge

Graeber D (2002) The new anarchists. New Left Review 13:61-73

Guthman J (2008) Neoliberalism and the making of food politics in California. Geoforum 39(3):1171-1183

Hardt M and Negri A (2009) Commonwealth. London: Harvard University Press

Hillebrand S and Zademach H M (2014) Alternative economies and spaces: Introductory remarks. In H M Zademach and S Hillebrand (eds) Alternative Economies and Spaces: New Perspectives for a Sustainable Economy (pp 9-23). Bielefeld: transcript Verlag

Holloway J (2010) Crack Capitalism. London: Verso

Jonas A (2010) Alternative this, alternative that...: Interrogating alterity and diversity. In D Fuller, A Jonas and R Lee (eds) Interrogating Alterity: Alternative Economic and Political Spaces (pp 13-27). Farnham: Ashgate

Jonas A (2014) Interrogating alternative local and regional economies: The British credit union movement and post-binary thinking. In $\mathrm{H}$ M Zademach and S Hillebrand (eds) Alternative Economies and Spaces: New Perspectives for a Sustainable Economy (pp 23-42). Bielefeld: transcript Verlag

Kasimis C and Papadopoulos A G (2013) Rural transformations and family farming in contemporary Greece. In D Ortiz-Miranda, A Moragues-Faus and E Arnalte-Alegre (eds) Agriculture in Mediterranean Europe: Between Old and New Paradigms (pp 263-293). Bingley: Emerald

Lawson V (2005) Hopeful geographies: Imaging ethical alternatives-a commentary on J K Gibson-Graham's "Surplus possibilities: Postdevelopment and community economies". Singapore Journal of Tropical Geography 26(1):36-38

MAGRAMA (2014) Encuesta de Precios de Tierra 2013. Madrid: Ministerio de Agricultura, Alimentación y Medio Ambiente

Montllor N (2013) El nuevo paradigma agrosocial, futuro del nuevo campesinado emergente. Polis (Santiago) 12(34):203-223

North P (2005) Scaling alternative economic practices? Some lessons from alternative currencies. Transactions of the Institute of British Geographers 30(2):221-233

Ploeg J (2008) The New Peasantries: Struggles for Autonomy and Sustainability in an Era of Empire and Globalization. London: Earthscan

Rakopoulos T (2014) The crisis seen from below, within, and against: From solidarity economy to food distribution cooperatives in Greece. Dialectical Anthropology 38(2):189-207

S4A (2015) Building Hope Against Fear and Devastation: Four Years of Resistance and Solidarity. Athens: Solidarity For All. http://issuu.com/solidarityforall/docs/report_2014 (last accessed 24 August 2016)

Samers M (2005) The myopia of "diverse economies", or, A critique of the "informal economy". Antipode 37(5):875-886

Sheppard E (2006) David Harvey and dialectical space-time. In N Castree and D Gregory (eds) David Harvey: A Critical Reader (pp 121-142). Oxford: Blackwell

Skordili S (2013) Economic crisis as a catalyst for food planning in Athens. International Planning Studies 18(1):129-141

Snow D A and Trom D (2002) The case study and the study of social movements. In B Klandermans and S Staggenborg (eds) Methods of Social Movement Research (pp 146-172). Minneapolis: University of Minnesota Press

The Guardian (2012) Greece on the breadline: "Potato movement" links shoppers and farmers. 18 March. http://www.theguardian.com/world/blog/2012/mar/18/greecebreadline-potato-movement-farmers (last accessed 22 August 2016)

Wright E O (2010) Envisioning Real Utopias. London: Verso

Youth Council of Euskadi (2010) "Jóvenes Baserritarras: Situación socioeconómica de la juventud agroganadera en la CAPV." Hizpideak 4, Euskadiko Gazteriaren Kontseilua 